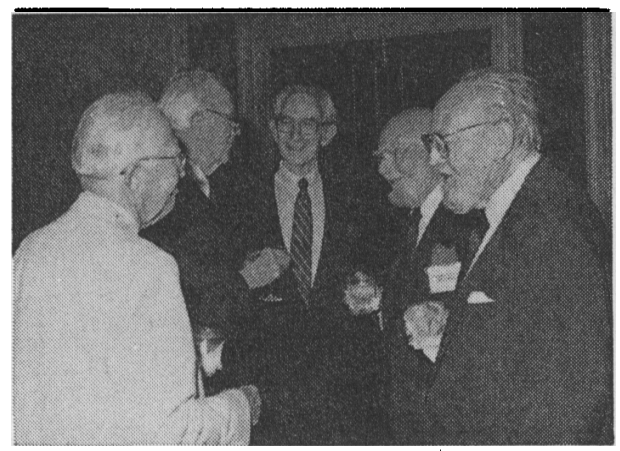

L. to $r$., former APSA Presidents C. Herman Pritchett, R. Taylor Cole, Heinz Eulau and Pendleton Herring share a moment with former APSA Executive Director, Evron Kirkpatrick.

Leon D. Epstein-1978-79

Warren E. Miller-1979-80

Seymour Martin Lipset-1981-82

William H. Riker-1982-83

Aaron Wildavsky-1985-86

Samuel P. Huntington-1986-87

Also attending were President Judith $\mathrm{N}$. Shklar, many spouses, and two former Executive Directors of the Association, Evron M. Kirkpatrick and Thomas E. Mann.

\section{APSA Annual Meeting Placement Service Continues to Grow}

No matter how much space is set aside for the Annual Meeting Placement Service in recent years, it never seems to be enough. The Atlanta Placement Service registered significant increases in the number of employers using the service, and the number of positions available. The decline in the number of applicants may be an early indication of changing market conditions in academia, or it may simply reflect the decline in applicant numbers that takes place when the Annual Meeting is held outside of Washington, D.C.
Annual Meeting Placement Services, 1986-89

\begin{tabular}{lrrrr}
\hline & 1986 & 1987 & 1988 & 1989 \\
\hline f Employers & 127 & 143 & 161 & 179 \\
f Applicants & 487 & 423 & 545 & 483 \\
f Positions & 213 & 227 & 252 & 282 \\
Other* & 6 & 9 & 4 & 15 \\
\hline
\end{tabular}

* Refers to listings with an unspecified number of vacancies.

\section{The End of Realignment?}

\section{Carol Nechemias \\ Pennsylvania State University-Harrisburg}

Chaired by Professor Harold F. Bass, Jr., of Ouachita Baptist University, the 1989 Harold Lasswell Symposium focused on a household word within our professionthe concept of realignment. Although all the papers, presented, respectively, by Professor Joel H. Silbey of Cornell University, Professor Everett Carll Ladd of the University of Connecticut and the Roper Center for Public Opinion Research,' and Professor Byron E. Shafer of Nuffield College (Oxford University), attacked the utility of realignment, their critiques shared little in common other than the view that realignment has obscured more than it clarifies. Faced with this critical onslaught, the discussants, Professor Walter Dean Burnham of the University of Texas, Austin, and Samuel T. McSeveney of Vanderbilt University, provided a counterbalance to what had become a "coroner's inquest."

Silbey presented an alternative approach to periodizations of American electoral history which rely on critical realigning elections. He argued that while significant changes have occurred in the American political universe, these changes were not necessarily coterminous with realigning elections. Characterizing the first 50 years under the Constitution as ones of a "volatile non-party system"' Silbey noted that the 1828 election could not be labelled a realigning election. He pointed out that 